Dr Waldemar Rydzak

Department of Economic Journalism and Public Relations

Poznan University of Economics

Al. Niepodległości 10/324B, 60-967 Poznan, Poland

waldemar.rydzak@ae.poznan.pl

\title{
CRISIS PUBLIC RELATIONS IN TRANSITION COUNTRIES
}

\begin{abstract}
Poland and Ukraine were a part of the Eastern block characterized by a centralized command economy that barred not only foreign enterprises but also any privately-held ventures from doing business. In 1989 most of society welcomed the advent of the free market with high hopes and great enthusiasm. PR became a set of tools employed to help the public administration introduce the necessary changes.

Towards the end of the 1990s, Poland saw waning enthusiasm and public approval for the transition process. Politicians would often speak critically of foreign companies, their tone picked up by the mass media.

The negative attitude of Polish society to foreign capital from the East was very noticeable during the privatisation of the Częstochowa Steelworks. Traditional PR strategies, including crisis communication management, which were successful in developed countries, as it turned out may be rather low in transition countries. The factor which lowers the quality of communication in crisis situations is the mentality of employees and the aversion of Polish managers towards journalists.
\end{abstract}

\section{Key words}

Economic Integration, Comparative Studies of Countries, Public relations, Crisis management, Communication 